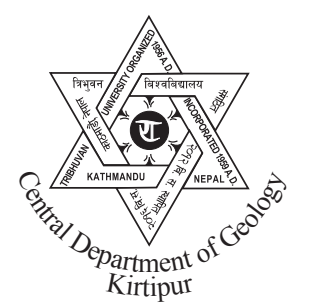

Bulletin of the Department of Geology

Bulletin of the Department of Geology, Tribhuvan University, Kathmandu, Nepal, Vol. 16, 2013, pp. 43-52

\title{
Geotechnical properties of construction aggregates from the Trishuli Ganga River, Galchi area, Central Nepal
}

\author{
Shailendra Shrestha and *Naresh Kazi Tamrakar \\ Central Department of Geology, Tribhuvan University, Kathmandu, Nepal
}

\begin{abstract}
The Trisuli Ganga River is rich in sand and gravel which are widely exposed along its banks. In recent years, quarry sites have been established and the materials have been supplied to markets. Apart from it the Trishuli III hydroelectric project is going to be established and for which a huge amount of construction aggregates will be required. From the study of sand and gravel as construction aggregates, it is found that the major composition of the sediments are metamorphosed rocks of the Lesser Himalayan rocks like gneiss, schist, quartzite, metasandstone, slate, granite, phyllite, etc. The gradation of coase aggregates range from dense to gap graded categories. Sulphate soundness value (SSV) and Los Angeles value (LAV) are $1.33-2.28 \%$ and $29.9-36.4 \%$, respectively. These ranges show ability of the aggregates to resist weathering and abrasion, and since these values lie within international specifications, the aggregates are suitable for various uses as; both asphaltic and concrete aggregates. Considering the fine aggregates, though they contain considerable amount of quartz grains, also contain exceeding amount of mica, and possesses poor workablity. Fineness modulus ranges between 6.07 and 7.63 , and exhibit dominantly sand size. Reduction of mica and further analysis for alkali-silica reactivity will enhance for its potential use.
\end{abstract}

Key words: Construction material, Gradation, Aggregate Crushing Value, Los Angeles Abrasion value

\section{INTRODUCTION}

Construction material plays a vital role in development of infrastuctures in the nation. From few years, sediments of the Trishuli Ganga River of Galchhi area are being used as concrete aggregates, which have markets in Kathmandu. The Trishuli Hydroelectric Project which is going to be established is also in search for the huge amount of construction aggregates. Quality of aggregates, which are used in concrete structures, is of great concerns. Smith and Collis (1993) identified main factors influencing aggregate behavior in various operational and environmental conditions, and concluded that the performance of aggregates depends upon their intrinsic

*Corresponding author:

E-mail address: ntamrakar@hotmail.com properties. Bajarnason et al. (2000) studied the unbound aggregates in road construction and have showed that for Icelandic basalt, the durability and abrasion were dependent on the degree of alteration while the fragmentation was dependent on porosity. Tamrakar et al. (2002) studied Siwalik sandstones from the Central Nepal and concluded that dry density and porosity were correlated well with uniaxial compressive strength, point load index and modulus ratio. Maharjan and Tamrakar (2003) evaluated quality of siltstone samples of the Tustung Formation for concrete aggregate. Dhakal et. al. (2006) conducted freeze-thaw experiments on the limestones and sandstones from Japan, and dolomite and schist from Nepal and showed that the rock samples were resistant to deterioration and breaking. They also concluded that initiation and extension of cracks and 


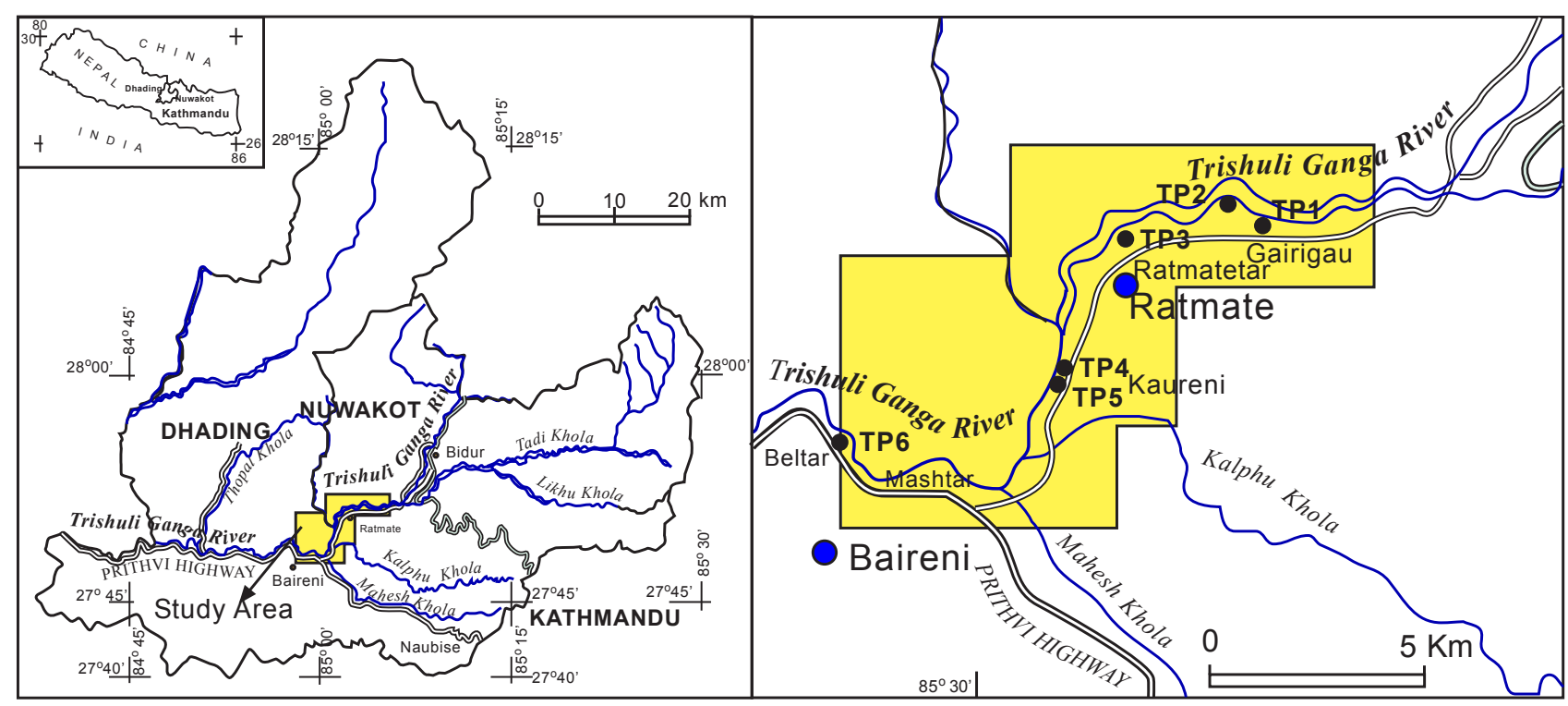

Fig. 1 Location map of study area and sampling sites.

subsequent wearing and deterioration occurred faster in high porosity rocks. Maharjan and Tamrakar (2007) evaluated quality of the river gravel from the Rapti and the Narayani Rivers, and concluded that the majority of gravels of both rivers were of high roundness and high sphericity, and of diverse chemical groups, and were compositionally sound with good workability for road and concrete aggregates. Therefore, study of properties of aggreagates are important to evaluate their usefulness in various uses as aggregates. The main aims of the present study are to analyse physical and mechanical properties of the material to evaluate their potential uses as construction aggregates.

\section{MATERIAL AND METHOD}

The samples for the study were obtained from the banks of the Trishuli Ganga River in Ratemate village, Ratemate VDC (Fig. 1). (Devighat-Galchhi Road). The area is characterized by more or less uniform topography with dominant river terrace along the Trishuli Ganga River corridor trending NE-SW. Mainly, the Upper Nuwakot group of the Nuwakot Complex and the Bhimphedi Group of the Kathmandu complex rocks are distributed in the study area (Stotöcklin, 1981; Stöcklin and Bhattarai 1977).

The Trishuli Ganga River is one the major tributaries of the Sapta Gandaki River. It is the snow as well as rain fed river. It confluences with the Koshi Khola from the west and the Kalphu Khola and the Mahesh Khola from the east, and then extends towards west till Mashtar. The river flows from the SE to the NW from Mashtar to Beltar (Fig. 1).

Six test pits were dug along the study area (Fig. 1 and Table 1). The test pit was dug of size 1 cubic metre (Fig. $2 a)$ in each of the six test pits distributed along the bars of the Trishuli Ganga River (Fig. 3). Some crushers are also found along the banks which have been utilizing the river gravel. The sample was sieved in the field at specified sieve size from $0.125 \mathrm{~m}^{3}$ volume at each location (Fig. 2). About $10 \mathrm{~kg}$ of sample were brought for further lab

Table1: Showing information of the location of sampling

\begin{tabular}{|c|c|c|c|c|}
\hline Test pit & Easting & Northing & $\begin{array}{l}\text { levation } \\
\text { (m) }\end{array}$ & Location \\
\hline TP1 & 603140 & 3082156 & 423 & $\begin{array}{l}\text { At right bank (RB) of } \\
\text { the Trishuli Ganga } \\
\text { River (TGR) in } \\
\text { Gairigau }\end{array}$ \\
\hline TP2 & 602706 & 3082222 & 421 & $\begin{array}{l}\text { At RB of the TGR } \\
\text { in Gairigau }\end{array}$ \\
\hline TP3 & 601750 & 3081930 & 413 & $\begin{array}{l}\text { At RB of the TGR } \\
\text { in Ratmatetar }\end{array}$ \\
\hline TP4 & 600510 & 3079250 & 409 & $\begin{array}{l}\text { At RB of the TGR } \\
\text { in Keureni }\end{array}$ \\
\hline TP5 & 600465 & 3079500 & 408 & $\begin{array}{l}\text { At RB of the TGR } \\
\text { in Keureni }\end{array}$ \\
\hline ТP6 & 595750 & 3078850 & 396 & $\begin{array}{l}\text { At Left Bank of the } \\
\text { TGR in Beltar }\end{array}$ \\
\hline
\end{tabular}




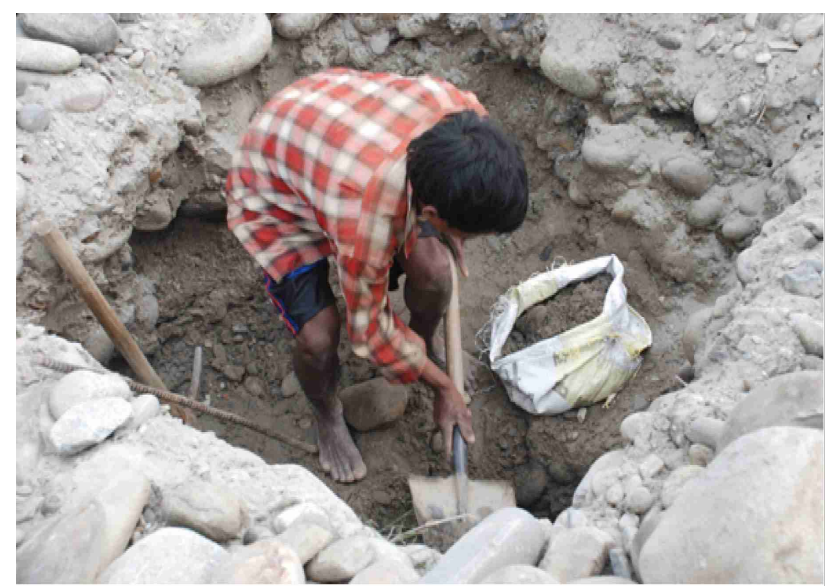

Fig. 2 A test pit for sieving of a sample in field.

analysis of composition, shapes and physical and mechanical properties. In the test pit there are sediments consists of boulder to sand size sediments which were well distributed.

Analyses were made for the coarse aggregates and the fine aggregates separately. The representative aggregate (pebbles) samples were selected from different test pits and cut into appropriate size in the laboratory. Fifteen thin sections of pebbles and six thin sections of the rock samples from the outcrop of different locations were prepared, among them all the thin sections were examined under petrographic microscope for the study of general mineralogical composition and texture. Similarly further sieving of the sand of its various sizes ASTM C136-06 (ASTM, 2010) and composition analysis was done by the help of stereoscopic microscope. To determine the composition of fine aggregates, firstly the fine aggregates were sieved in specified sieves, then each
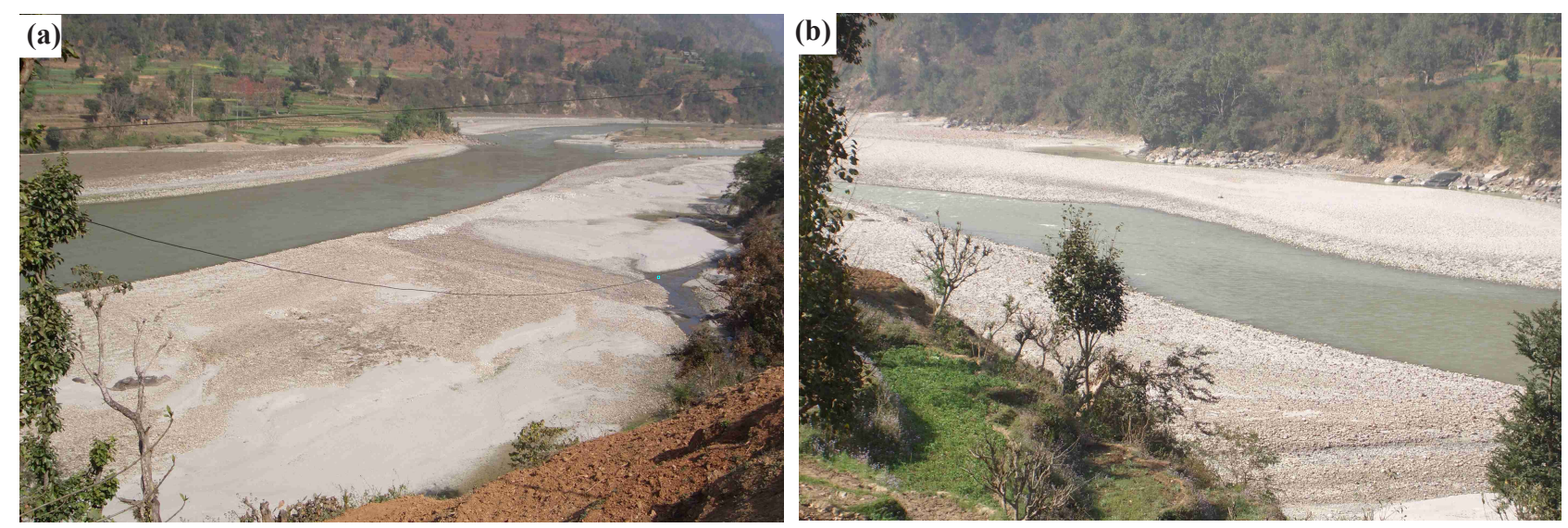

Fig. 3 (a) An upstream view of the Trishuli Ganga River at the sampling site TP 4, and (b) A downstream view of the same at the site TP5. 
the corresponding sieves.

The physical properties such as water absorption and dry density, and specific gravity were determined after AASTHO T85-81 (AASHTO, 1982b). Samples were immersed in water for 24 hours, surface dried, weighed and percent absorption relative to dry weight were calculated as:

Water absorption $=\left\{\left(\mathrm{W}_{2}-\mathrm{W}_{1}\right) / \mathrm{W}_{1}\right\} \times 100 \%$

where, $\mathrm{W}_{1}=$ Weight of oven dried sample, and $\mathrm{W}_{2}$ =Weight of the surface dry saturated sample.

Specific gravity (SG) is a mass of a given substance divided by unit mass of an equal volume of water. Depending on the moisture condition, specific gravity can be oven dried, or saturated surface dry. Apparent specific gravity (ASG) is given by the ratio of density of the particles to the density of the water.

Los Angles Abrasion test were made following ASTM C131 to obtain mechanical soundness or hardness against abrasion of aggregate. The number of sphere charged were 12. The initial weight used was $5 \mathrm{~kg}$. The number of revolution of the drum was 500 . To obtain soundness of aggregates against frosting and chemical weathering, sulphate soundness test was made based on ASTM C88-05 (ASTM, 2005, 2010). The sodium sulphate soundness value (SSV) in percentage was obtained as the relative loss of the fine $(<10 \mathrm{~mm})$ after five cycles of test. Sulphate soundness value greater than $10 \%$ indicates that the sample is chemically unsound ASTM C33 (ASTM, 1994).

\section{RESULTS OF GEOTECHNICAL ANALYSIS OF COARSE AGGREGATE}

Geotechnical analysis provides the physical, mechanical and chemical properties of the aggregates, which help to evaluate quality of the aggregates.

\section{Composition}

The aggregates from the river deposits contain different types of rock fragments. Pebbles from different test pits

Table 2: (a) Composition of the pebbles in two different size grades, from different test pits

\begin{tabular}{|c|c|c|c|c|c|c|c|c|c|c|}
\hline \multirow{2}{*}{$\begin{array}{l}\text { Test pit } \\
\text { Sieve }\end{array}$} & \multicolumn{2}{|c|}{ TP1 } & \multicolumn{2}{|c|}{ TP2 } & \multicolumn{2}{|c|}{ TP3 } & \multicolumn{2}{|c|}{ TP4 } & \multicolumn{2}{|c|}{ TP5 } \\
\hline & $19 \mathrm{~mm}$ & $9.5 \mathrm{~mm}$ & $19 \mathrm{~mm}$ & $9.5 \mathrm{~mm}$ & $19 \mathrm{~mm}$ & $9.5 \mathrm{~mm}$ & $19 \mathrm{~mm}$ & $9.5 \mathrm{~mm}$ & $19 \mathrm{~mm}$ & $9.5 \mathrm{~mm}$ \\
\hline Fresh gneiss, $\%$ & 43 & 25 & 46 & 41 & 28 & 39 & 43 & 39 & 57 & 35 \\
\hline Fresh schist, \% & 39 & 23 & 32 & 17 & 38 & 13 & 29 & 27 & 29 & 13 \\
\hline Quartzite, \% & 4 & 3 & 7 & 11 & 3 & 7 & 29 & 8 & 14 & 13 \\
\hline Slightly altered gneiss, $\%$ & & & & 2 & 13 & 2 & & & & 12 \\
\hline Slightly altered schist, $\%$ & & & 4 & 3 & & 2 & & & & 4 \\
\hline Phyllite, \% & & & & 5 & & 2 & & 11 & & 4 \\
\hline Slate, $\%$ & & & & 2 & & 4 & & & & 2 \\
\hline Granite, $\%$ & 13 & 8 & 11 & 15 & 19 & 19 & & 14 & & 12 \\
\hline Meta-sandstone, $\%$ & & & & 5 & & 12 & & 2 & & 2 \\
\hline
\end{tabular}

Table 2: (b) Modal composition of the selected pebbles from different test pits

\begin{tabular}{|c|c|c|c|c|c|c|c|c|c|c|c|c|}
\hline Minerals \% & PS1 & PS 2 & PS11 & PS 21 & PS 22 & PS 23 & PS 24 & PS 25 & PS 26 & PS 31 & PS 32 & PS5 \\
\hline Quartz & 15 & 70 & 70 & 50 & 60 & 70 & 75 & 80 & 50 & 70 & 65 & 20 \\
\hline Feldspar & & 5 & 15 & 5 & 10 & 10 & & 5 & 10 & 20 & 15 & \\
\hline Mica & 5 & 25 & 15 & 10 & 20 & 20 & 15 & 5 & 30 & 10 & 20 & 10 \\
\hline Clay mineral & 80 & & & 35 & & & 10 & 10 & & & & 70 \\
\hline Garnet & & & & & 10 & & & & 10 & & & \\
\hline Total \% & 100 & 100 & 100 & 100 & 100 & 100 & 100 & 100 & 100 & 100 & 100 & 100 \\
\hline Rock type & Slate & Gneiss & Granite & Schist & Gneiss & Gneiss & $\begin{array}{c}\text { Meta- } \\
\text { sandstone }\end{array}$ & $\begin{array}{c}\text { Meta- } \\
\text { sandstone }\end{array}$ & Schist & Granite & Gneiss & Slate \\
\hline
\end{tabular}



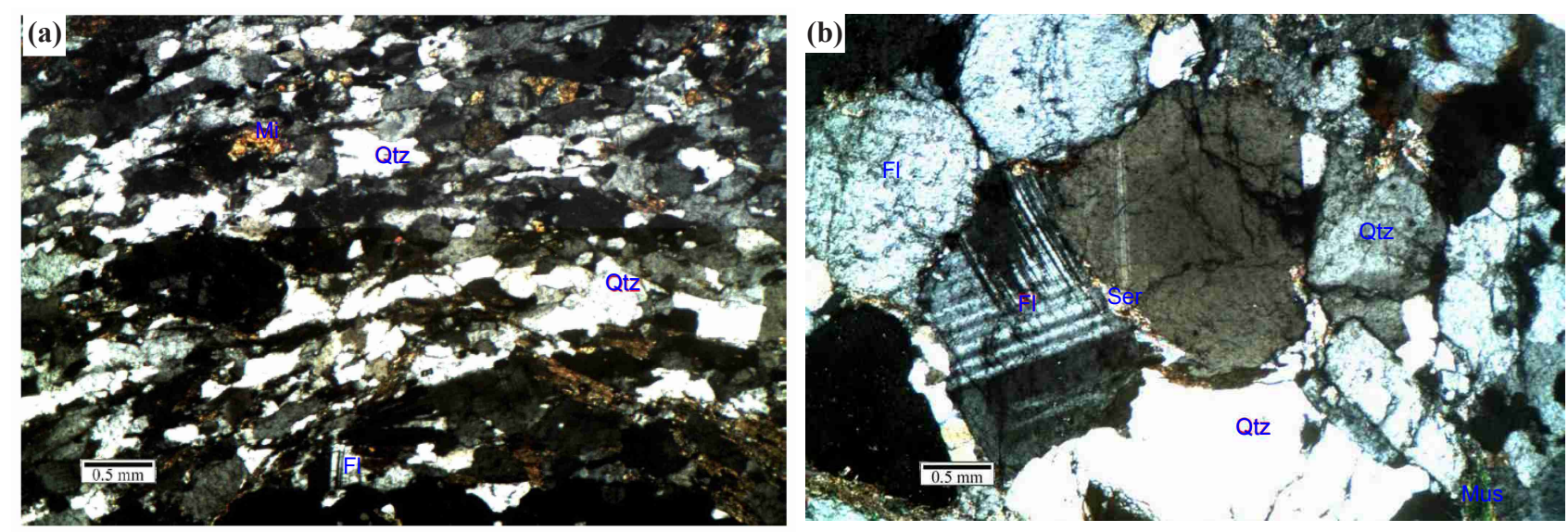

Fig. 4 Photomicrographs of pebbles: (a) Schist, P26, and (b) Granite, P24. Qtz = quartz; Fl = feldspar; Mi = mica; Mus = muscovite; Ser $=$ sericite

were collected and thin sections were prepared and investigated under petrographic microscope and composition and the rock types were identified. The results are liste in Table 2. The coarse aggregates contain maximum percentage of metamorphic rock particles, and few granite and meta-sandstone (Fig. 4a and 4b).

\section{Gradation}

The sieving was carried out in different test pits while collecting the samples, therefore the data collected were according to the passing percentage. They were placed in a table and the semi log graph plot was prepared to analyse the gradation of the aggregate (Table 3 ).

The maximum size for TP2, TP4, TP5 and TP6 is $300 \mathrm{~mm}$, whereas the nominal size is 200 for these samples. The nominal size of TP1 and TP3 is $300 \mathrm{~mm}$.

Table 3: The sieve passing percentage of different test pits

\begin{tabular}{ccccccc}
\hline Test Sieve & \multicolumn{7}{c}{ Total Passing \% } \\
\cline { 2 - 7 } Size $(\mathrm{mm})$ & TP1 & TP2 & TP3 & TP4 & TP5 & TP6 \\
\hline 300 & 85.6 & 100 & 86.77 & 100 & 100 & 100 \\
200 & 79.99 & 79.62 & 62.46 & 70.62 & 91.9 & 79.07 \\
80 & 49.31 & 53.78 & 45.57 & 57.93 & 58.9 & 68.83 \\
40 & 28.72 & 27.81 & 28.77 & 41.26 & 38.1 & 33.32 \\
20 & 21.25 & 19.87 & 20.59 & 34.85 & 27 & 20.88 \\
10 & 15.49 & 18.81 & 16.51 & 30.53 & 20.2 & 16.42 \\
4.75 & 11.04 & 17.9 & 14.28 & 28.56 & 15.9 & 14.88 \\
2.36 & 10.26 & 16.32 & 13.94 & 28.07 & 14.6 & 14.32 \\
1.18 & 9.15 & 14.64 & 13.45 & 27.4 & 12.8 & 14.02 \\
0.6 & 8.44 & 10.68 & 12.31 & 23.08 & 10.3 & 12.4 \\
0.3 & 5.79 & 4.63 & 7.54 & 6.51 & 5.42 & 6.94 \\
0.15 & .2 .44 & 1.68 & 3.32 & 2.2 & 1.91 & 2.26 \\
0.075 & 1.48 & 1.05 & 1.87 & 1.78 & 1.42 & 0.23 \\
\hline
\end{tabular}

Grading curves are of five kinds, i.e., dense graded, gap-graded, uniformly graded, well graded and open graded. Dense and well-graded aggregates are very much

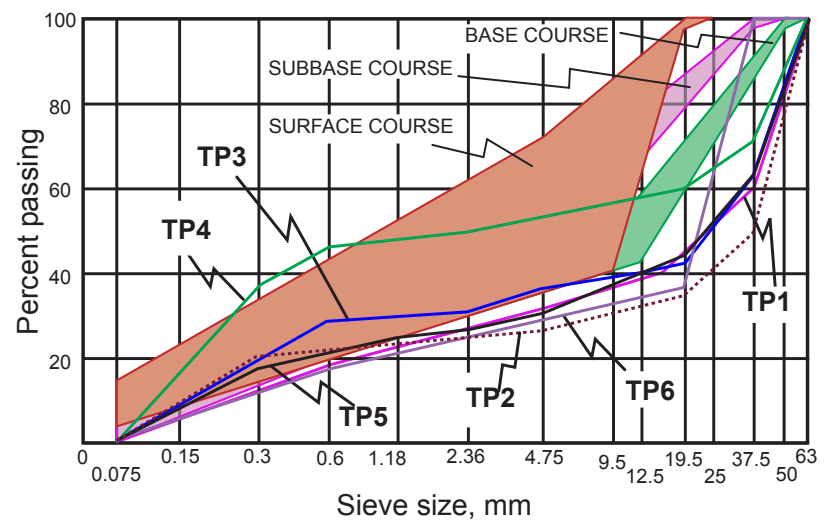

Fig. 5 Gradation graph for Base, Sub-base and Surface course material (The gradation limits are after FHWA FP-96 (Robert et al., 1996)).

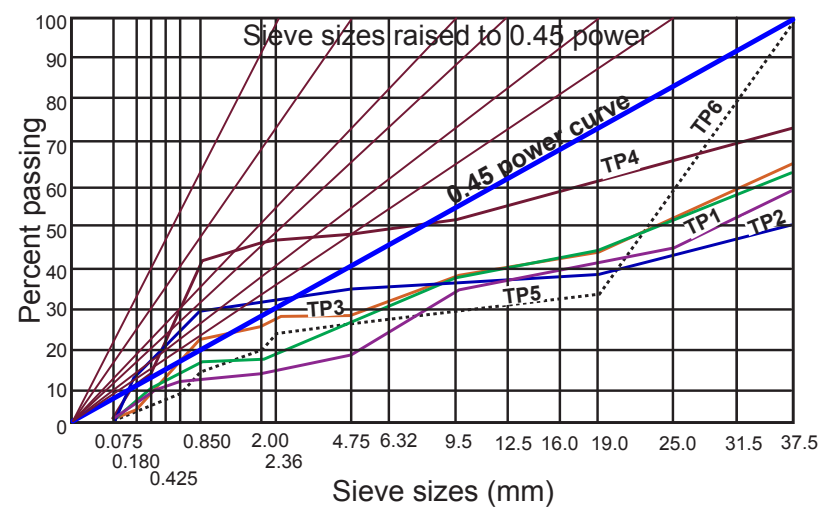

Fig. 6 Gradation of different sample in 0.45 power graph (The power graph is after FHWA FP-96 (Robert et al., 1996)). 
Table 4: The elongation index and flakiness index

\begin{tabular}{cccc}
\hline S. No & Test pit & Elongation Index $\%$ & Flakiness Index $\%$ \\
\hline 1 & TP1 & 29 & 27 \\
2 & TP2 & 35 & 10 \\
3 & TP3 & 39 & 17 \\
4 & TP4 & 31 & 20 \\
5 & TP5 & 32 & 28 \\
6 & TP6 & 23 & 18 \\
\hline
\end{tabular}

Table 5: The Specific gravity and water absorption value

\begin{tabular}{ccccc}
\hline Test pit & $\begin{array}{c}\text { Specific } \\
\text { gravity Oven } \\
\text { Dry, } \mathrm{G}_{\mathrm{OD}}\end{array}$ & $\begin{array}{c}\text { Specific } \\
\text { gravity, } \\
\text { Saturated } \\
\text { Surface } \\
\text { Dry, } \mathrm{G}_{\mathrm{SSD}}\end{array}$ & $\begin{array}{c}\text { Apparent } \\
\text { Specific } \\
\text { Gravity, } \mathrm{G}_{\mathrm{A}}\end{array}$ & $\begin{array}{c}\text { \% Water } \\
\text { Absorption, } \\
\text { WA }\end{array}$ \\
\hline TP2 & 2.675 & 2.661 & 2.667 & 0.36 \\
TP3 & 2.653 & 2.669 & 2.695 & 0.58 \\
TP4 & 2.619 & 2.639 & 2.673 & 0.77 \\
TP6 & 2.678 & 2.688 & 2.705 & 0.38 \\
\hline
\end{tabular}

suitable for concrete structure, because the space between larger particles is effectively filled by smaller particles to produce a well-packed structure. Gap-grading is a kind of grading which lacks one or more intermediate size, and is only used in concrete when the required workability is relatively low. For the uniform grading, only a few sizes dominate the bulk material. With this grading, the aggregates are not effectively packed, and the resulting concrete will be more porous, unless a lot of paste is employed. The open graded contains too much small particles and easy to be disturbed by a hole. The samples TP4 represent slightly dense grading (Figs. 5 and 6) which is appropriate for concrete structures. The remaining samples fall on to the gap graded in which the size ranges from 1 to 10 or $20 \mathrm{~mm}$ are very low. The blending of this size range may be required to increase workability of concrete.

\section{Shape Indices}

The results of shape indices measurements (Table 4) show that the coarse aggregate of the samples from TP6 is more suitable since it has less EI and FI. The flakiness indices of TP1 and TP5 exceed the specified limit of $25 \%$ after BS 812 Part 105.1 (BS,1989), whereas the elongation indices of all the samples except TP6 exceed the limit $(<25 \%)$ of BS812 Part 105.2 (1990).

\section{Specific Gravity and Water Absorption}

The specific gravity ranges from 2.667 to 2.705 (Table 5). The aggregates belongs to heavy weight aggregates (Sp. Gr. >2.6) according to ASTM C 127 (1989). The water absorption value (WAV) ranges from $0.36 \%$ to $0.77 \%$, and indicates very low effective porosity. It lies within the specification ( $<2 \%$ ) of ASTM C 128 (1989). Low WAV prevents access of reactants to aggregate to attack and therefore aggregates will be strong enough to withstand chemical reaction against cement and weathering fluids. WAV also relates closely to some other undesirable properties such as poor resistance to frost action and chemical reaction with foreign materials.

\section{Los Angeles Abrasion Value}

There is no large variation in the composition and the texture of the samples tested within the different test pits. The samples from all the test pits of "Grade A" were prepared to test the Los Angles Abrasion Test. The Los Angles abrasion values of the samples range from 29.9\% to $36.4 \%$ (Table 6). According to the results of the tests, these aggregates can be used for base coarse of the road (ASTM, 1979). Except TP3, since the other samples show values $<35 \%$, they thus meet specifications of AASHTO T 96 (1982b), ASTM C131, NS: 297 (1994) and DOR (2001). It means that these aggregates are suitable for wide range of application from Portland concrete aggregate to road aggregates (Asphaltic pavement to base course and sub base course).

Table 6: Result of Los Angles Abrasion Test

\begin{tabular}{lccc}
\hline & $\begin{array}{c}\text { Wt. retained on } \\
\# 12 \text { sieve }(\mathrm{gm})\end{array}$ & $\begin{array}{c}\text { Wt. passing on } \\
\# 12 \text { sieve }(\mathrm{gm})\end{array}$ & LAV (\%) \\
\hline TP1 & 3240 & 1760 & 35.2 \\
TP2 & 3340 & 1660 & 33.2 \\
TP3 & 3180 & 1820 & 36.4 \\
TP4 & 3440 & 1560 & 29.9 \\
TP5 & 3250 & 1750 & 35 \\
TP6 & 3400 & 1600 & 32 \\
& & Specifications
\end{tabular}

AASHTO T 96 (1982b) <40\% for PCC and bituminous mix

ASTM C $131 \quad(30-50 \%)$ but usually $<40 \%$ : $<30 \%$ Bituminous mix, $<50$ Base course, $<16$ PCC

NS: 297 (1994) $\quad<30 \%$ Road and concrete structures, and $<45 \%$ Others

DOR (2001) $\quad<30-35 \%$ Base course and $<40 \%$ Sub-base; For MACADAM: $<40$ Base and $<45 \%$ Sub-base 
Table 7: Result of sulphate soundness test value

\begin{tabular}{cccc}
\hline Sample No. & $\begin{array}{c}\text { Initial weight } \\
\mathrm{W}_{1}\end{array}$ & $\begin{array}{c}\text { Final weight } \\
\mathrm{W}_{2}\end{array}$ & $\begin{array}{c}\mathrm{SSV} \\
(\%)\end{array}$ \\
\hline TP2 & 2815.2 & 2766.5 & 2.28 \\
TP3 & 2808.6 & 2768.5 & 1.57 \\
TP4 & 2813.7 & 2766.7 & 1.8 \\
TP6 & 2821.7 & 2784.6 & 1.33 \\
\multicolumn{4}{c}{ Specification } \\
ASTM C33 (1994) & $10 \%$ loss at 5 cycle (for PCC, Asphalt) \\
AASHTO T 104 & $12 \%$ loss at 5 cycle (surfacing \\
(1982c) & and foundation courses) \\
\hline
\end{tabular}

\section{Sulphate Soundness Value}

The calculated SSV range from 1.33 to $2.28 \%$ (Table 7). The calculated SSV for the all the samples of Trishuli River are below 10\%. This means the aggregates samples are sound and are resistance against chemical weathering and frost susceptibility.

\section{GEOTECHNICAL PROPERTIES OF FINE AGGREGATE}

\section{Composition}

The fine aggregates retained on specified sives Table 8 ) were considered for compositional analysis. The fine aggregates are composed dominantly of quartz $(67.5 \%$ $-74.7 \%$ ) (Table 9 and Fig. 7). The other remarkable constituents are mica $(10.7 \%-28.3 \%)$ and metamorphic rock fragments (0-5.6\%) (Table 9). Since high percentage of quartz exists and organic material is absent, the fine aggregate is sound. However, the excessive presence of micas may bring about pop-out failure, and complicate workability.

\section{Gradation and Shape}

The fineness modulus for fine aggregate should lie between 2.3 and 3.1 (ASTM C33, 1994). A small number indicates a fine grading; whereas larger number indicates a coarse material. From Table 10, the value of the fineness modulus is larger (6.07-7.63), thus the grain size of the fine aggregates is coarse, and contains maximum percent of sand size particles rather than silt and clay.

More than $95 \%$ of grains were equant; only about $5 \%$ grains were elongate and flake, thus the fine aggregates exhibit good workability.

\section{Specific gravity and water absorption}

The water absorption value (WAV) of fine aggregates ranges from $0.95 \%$ to $1.0 \%$. According the specification of BS 812-2 (1995), WAV should be $<3 \%$ for overall uses of aggregates. AASHTO T 85 (1982a) specifies WAV $<5 \%$ for the general use. But ASTM C 127 has specified that this should be $<2.5 \%$ for fine aggregates and $<2.0$ for coarse aggregates. Because the recorded WAVs for six test pit samples of fine aggregates are below $2 \%$ showing low effective porosity, there are wide possibilities of applicability of these aggregates in construction.

Table 8: Weight of sample retained on specified sieves

\begin{tabular}{lccccc}
\hline Sample & $\begin{array}{c}2 \mathrm{~mm} \\
\text { retained } \\
\text { gm }\end{array}$ & $\begin{array}{c}600 \mu \mathrm{m} \\
\text { retained } \\
\text { gm }\end{array}$ & $\begin{array}{c}250 \mu \mathrm{m} \\
\text { retained } \\
\text { gm }\end{array}$ & $\begin{array}{c}0.75 \mu \mathrm{m} \\
\text { retained gm }\end{array}$ & Pan gm \\
\hline TP1 & 97.1 & 472.7 & 364 & 180.1 & 30.7 \\
TP2 & 201.6 & 644.6 & 491.8 & 293.8 & 34.3 \\
TP3 & 15.5 & 75.6 & 946.5 & 235.4 & 12.3 \\
TP4 & 6.6 & 214.4 & 1157.6 & 471.5 & 19.1 \\
TP5 & 34.5 & 424.2 & 594.1 & 283.5 & 25.6 \\
TP6 & 171 & 142.4 & 39.6 & 44.6 & 17.6 \\
\hline
\end{tabular}

Table 9: Weighted percent constituent of fine aggregate samples

\begin{tabular}{lcccccc}
\hline \multirow{2}{*}{ Constituent } & \multicolumn{6}{c}{ Weighted percent constituents } \\
\cline { 2 - 7 } & TP1 & TP2 & TP3 & TP4 & TP5 & TP6 \\
\hline Quartz & 67.5 & 73.7 & 68.3 & 74.7 & 73.6 & 70.2 \\
Feldspar & 2 & 0.7 & 0.3 & 3.5 & 0.8 & 11.9 \\
$\begin{array}{l}\text { Metamorphosed } \\
\text { rock fragment }\end{array}$ & 5.6 & 4.6 & 2.9 & 3.2 & 3.5 & - \\
$\begin{array}{l}\text { Igneous rock } \\
\text { fragment }\end{array}$ & 0.5 & 0.4 & - & - & - & 6.2 \\
$\begin{array}{l}\text { Mica } \\
\text { Clay/silt size }\end{array}$ & 22.5 & 17.2 & 28.3 & 18.2 & 21.6 & 10.7 \\
particles & 0.3 & 0.6 & - & - & - & - \\
Heavies & 1.6 & 2.8 & 0.2 & 0.4 & 0.5 & 1 \\
Total & 100 & 100 & 100 & 100 & 100 & 100 \\
\hline & & & & & & \\
\hline
\end{tabular}

Table 10: Fineness modulus of the samples Sample no

\begin{tabular}{cc}
\hline Sample no & Fineness modulus \\
\hline TP1 & 7.63 \\
TP2 & 7.48 \\
TP3 & 7.02 \\
TP4 & 6.07 \\
TP5 & 7.45 \\
TP6 & 7.18 \\
\hline
\end{tabular}



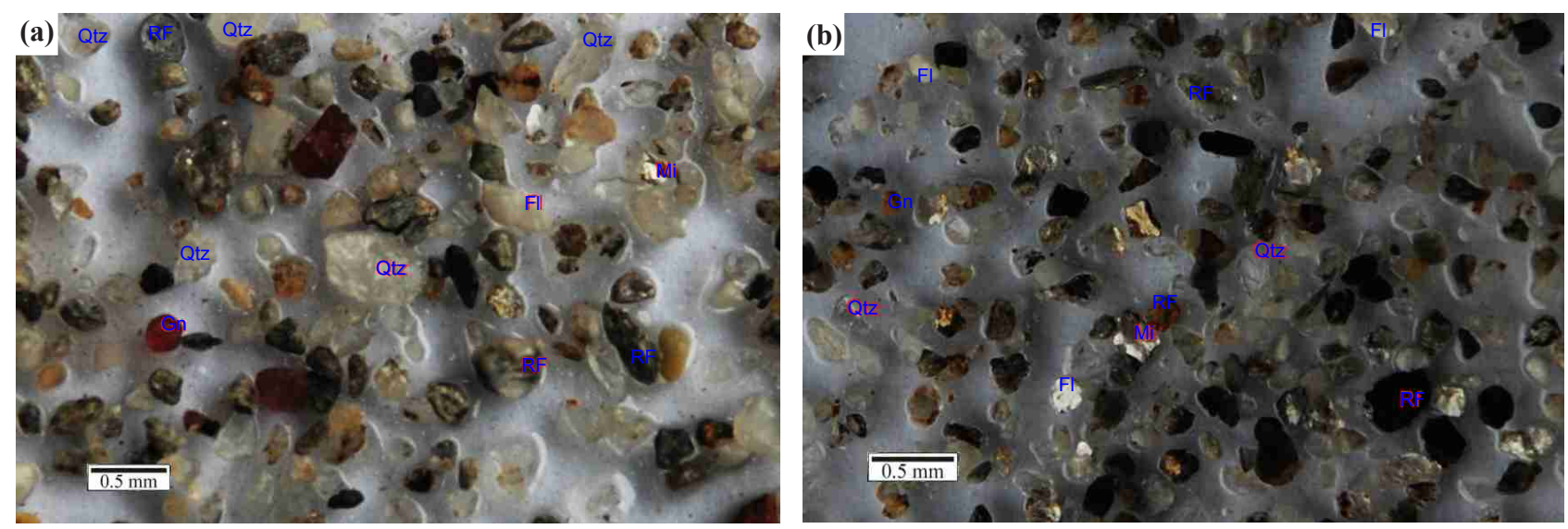

Fig. 7 : Photo micrograph of fine aggregates of size 600 microns: (a) Sample TP2, and (b) Sample TP3. Qtz = quartz, Fl = feldspar; $\mathrm{Mi}=$ mica; $\mathrm{RF}=$ rock fragment; $\mathrm{Gn}=$ garnet.

\section{Sulphate Soundness Value}

According to ASTM C33 (1994), sulphate soundness value greater than $10 \%$ indicates chemically unsound aggregate. The calculated SSV for fine aggreagates ranges from $1.36 \%$ to $3.25 \%$, suggesting that the aggregate samples are sound and are resistant against chemical weathering and frost susceptibility.

\section{EVALUATION OF AGGREGATES}

\section{Coarse Aggregates}

The samples from all the test pits contain dominantly the gneiss fragments and subordinately other metamorphic and igneous rock fragments which give mixed type aggregate (Table 11). The Trishuli Ganga River is originated from the Higher Himalaya region and the site of quarry lies in Lesser Himalaya region, so that the sediments mostly contains metamorphosed rocks basically of gneiss, quartzite, schist, etc. Gneiss and quartzite are high quality rocks but schist with high mica content are deleterious to the aggregate.The aggregates of almost all the test pits show gap gradation, and will need blending to get grading as appropriate for PCC mix design.

The dry density lies between light and heavy aggregate. The ASTM 1994 recommended that the WAV should exeed 3\%. ASTM C127 and ASTM C128 suggested, respectively the WAV maximum level of 2.0 (coarse aggregate) and 2.3 (fine aggregate) for concrete aggregate. According to AASHTO T85 (1982a), WAV should be within 5\% for all end uses, and according to BS 812-2 it should be within $3 \%$. As WAV of all the samples tested are less than $3 \%$, the aggregates meet all the above mentioned standards.

Table 11: Overall results of analysis of coarse aggregate and their evaluation

\begin{tabular}{|c|c|c|c|c|c|}
\hline Sample No. & Composition of aggregates & $\begin{array}{l}\text { Apparent } \\
\text { Specific } \\
\text { Gravity }\end{array}$ & Water Absorption Value & $\begin{array}{l}\text { Los Angles } \\
\text { Abrasion } \\
\text { Value }\end{array}$ & $\begin{array}{l}\text { Sulphate Soundness } \\
\text { Value }\end{array}$ \\
\hline TP2 & Gneiss, Schist, Quartzite, Granite & 2.667 & 0.36 & 33.2 & 2.28 \\
\hline TP3 & Gneiss, Schist, Quartzite, Granite & 2.695 & 0.58 & 36.4 & 1.57 \\
\hline TP4 & Gneiss, Schist, Quartzite & 2.673 & 0.77 & 29.9 & 1.8 \\
\hline \multirow[t]{3}{*}{ TP6 } & Gneiss, Schist, Quartzite, Granite & 2.705 & 0.38 & 32 & 1.33 \\
\hline & & \multicolumn{4}{|c|}{ Evaluation of coarse aggregates } \\
\hline & $\begin{array}{l}\text { Some schist fragments with high } \\
\text { mica content are deleterious } \\
\text { constituents and should be sorted } \\
\text { while processing the aggregates }\end{array}$ & $\begin{array}{l}\text { Heavy } \\
\text { weight } \\
\text { aggregates }\end{array}$ & $\begin{array}{l}\text { Low: fluid passage will be } \\
\text { difficult to deteriorate the } \\
\text { aggregate mass in any } \\
\text { form of end-uses; concrete, } \\
\text { asphaltic mix, base course, } \\
\text { sub-base and wearing course }\end{array}$ & $\begin{array}{l}\text { Moderately } \\
\text { high (but } \\
<40 \% \text { as many } \\
\text { standards have } \\
\text { specified) }\end{array}$ & $\begin{array}{l}\text { Far less compared to the } \\
10-12 \% \text { specification } \\
\text { and therefore aggregates } \\
\text { show resistance to frost } \\
\text { weathering and alteration } \\
\text { against salt weathering }\end{array}$ \\
\hline
\end{tabular}


Geotechnical properties of construction aggregates from the Trishuli Ganga River, Galchi area, Central Nepal

Table 12: Overall results of fine grain aggregates and their evaluation

\begin{tabular}{|c|c|c|c|c|c|}
\hline Sample No. & $\begin{array}{l}\text { Apparent } \\
\text { Specific } \\
\text { Gravity }\end{array}$ & Water Absorption Value & $\begin{array}{l}\text { Los Angles } \\
\text { Abrasion Value }\end{array}$ & $\begin{array}{l}\text { Sulphate } \\
\text { Soundness } \\
\text { Value }\end{array}$ & $\begin{array}{l}\text { Composition of } \\
\text { aggregates }\end{array}$ \\
\hline TP1 & 2.782 & 0.95 & 35.2 & 3.25 & $\begin{array}{l}\text { Quartz, Feldspar, Mica, } \\
\text { Rock fragments, Clay } \\
\text { minerals }\end{array}$ \\
\hline TP5 & 2.767 & 1 & 35 & 1.36 & $\begin{array}{l}\text { Quartz, Feldspar, Mica, } \\
\text { Rock fragments }\end{array}$ \\
\hline \multicolumn{6}{|c|}{ Evaluation of fine aggregates } \\
\hline & $\begin{array}{l}\text { Heavy } \\
\text { weight } \\
\text { aggregates }\end{array}$ & $\begin{array}{l}\text { Low: fluid passage will be difficult } \\
\text { to deteriorate the aggregate mass } \\
\text { in any form of end-uses; concrete, } \\
\text { asphaltic mix, base course, } \\
\text { sub-base and wearing course }\end{array}$ & $\begin{array}{l}\text { Moderately high } \\
\text { (but between } 30 \% \\
\text { and } 50 \% \text { of } \\
\text { standards) }\end{array}$ & $\begin{array}{l}\text { Far less } \\
\text { compared to } \\
\text { the } 10-12 \% \\
\text { specifications }\end{array}$ & $\begin{array}{l}\text { Mica and clay minerals are } \\
\text { deleterious constituents } \\
\text { and should be sorted while } \\
\text { processing the } \\
\text { aggregates }\end{array}$ \\
\hline
\end{tabular}

The Los Angles abrasion value (LAV) of sample lies between 29.9\% and 36.4\%. Khanna and Justo (2000) suggested lower range of LAV generally not suitable for concrete aggregate however it is suitable for surface course of a road. According to NS 297, (NS, 1994), it can be used for concrete surface and wearing road. ASTM C131 specified LAV of $<30 \%$ for bituminous mixture, and between 30 and 50\% for Portland cement concrete. Though the LAV obtained for the present samples is slightly excess for bituminous mixture, it is suitable for rest of the end uses.

AASHTO T 104 (1982c) specified SSV of five cycles to be within $10 \%$ for PCC and asphaltic mix, and that below $12 \%$ for surfacing material and other courses. The minimum value for SSV for coarse aggregates to allow for concrete is $10 \%$ (ASTM C88, 2005). Since the SSV of all the samples are less than $10 \%$, therefore the aggregate samples are sound and are resistance against abrasion.

\section{Fine Aggregates}

Fine aggregates contain high percent of quartz particles ranging from $67.5 \%$ to $74.7 \%$ (Table 12 ). Similarly, mica also showed remarkable amount ranging from $10.7 \%$ to $28.3 \%$ since the aggregates are sourced to metamorphic rocks such as gneiss and schist. The samples offer fair for construction purpose, as there are sufficient presence of micas as deleterious constituent, which should not exceed $5 \%$.
The dry densities of the fine aggregate samples are low. The WAV of the samples is less than 2.7 (Table 12) which is less than $3 \%$ (ASTM C128<2.3\%; BS 812-2 $<3 \%$ ), thus the aggregates are suitable for concrete cement as well as in asphaltic mixes and other courses. The SSV of samples TP1 and TP5 was less than 10\% in accordance with the ASTM C88 (2005).

\section{CONCLUSION}

From the study of the sediments from the Trisuli Ganga River, it is found that the major composition of the sediments are metamorphosed rocks of the Lesser Himalayan rocks like gneiss, schist, quartzite, metasandstone, slate, granite, phyllite, etc.

According to the gradation of the samples it is clear that the samples are suitable for bituminous bound aggregates as well as in base and sub-base course materials. Most of the sediments are dense to gap graded requiring blending for gap graded ones. Since the SSV is less than $10 \%$ aggregates are resistance against chemical weathering and frost susceptibility. The LAV is also sound for aggregates for asphalt and concrete use. Fine aggregates contain exceeding amount of mica, which causes poor workability. As aggregates are rich in quartz and are derived from varied sources, it is further recommended to analyse these aggregates for alkalisilica reactivity. Thus the aggregates from the banks of The Trishuli Ganga River are appropriate for the construction material, only after some treatment in grading and some further analysis. 


\section{ACKNOWLEDGEMENTS}

The article is related to the M. Sc. dissertation of the first author who received support as well as field and laboratory facilities from East Management Service, Latitpur. Authors are thankful to East Management Service and Central Department of Geology for providing necessary facilities.

\section{REFERENCES}

AASHTO, 1982a. Specific gravity and absorption of coarse aggregate, Standard No. T85-81, Standard Specifications for Transportation materials and Methods of Sampling and Testing (Part III), The American Association of State Highway and Transport Officials (AASHTO), pp. 266.

AASHTO,1982a. Soundness of aggregate by use of sodium Sulphate, Standard No.T104-77, Standard Specifications for Transportation Materials and Methods of Sampling and Testing (Part II), the American Association of State Highway and Transport Officials (AASHTO), pp. 335.

AASHTO,1982b. Los Angeles Abrasion Test, Standard No.T96-77. Standard Specifications for Transportation Materials and Methods of Sampling and Testing (Part II), the American Association of State Highway and Transport Officials (AASHTO), pp. 198.

ASTM, 2010. Standard Test Method for Sieve Analysis of Fine and Coarse Aggregates C-136-03.

ASTM, 1979. Standard test method of test for Triaxial Compressive Strength of undrained rock core specimen without pore pressure measurements.Annual book of ASTM Standard $632 \mathrm{p}$.

ASTM, 1981. Test for resistance to degradation of large sized coarse aggregates by abrasion and impacts in the Los Angeles Machine. ASTM C131.

ASTM International, 1989. Density, Relative Density (Specific Gravity), and Absorption of Coarse Aggregate, ASTM C 127-88.

ASTM Intgernaltional, 1994. Standard Specification for Concrete Aggregates, ASTM C 33-03. pp.1-11.

ASTM International, 2005. Standard test method for Soundness of Aggregates by use of sodium sulphate or magnesium sulphate. C88-05, pp. 1-5.

Bajarson, G., Petursson, P., and Erlingsson, S., 2000. Aggregate resistance to fragmentation, weathering and abrasion. Unbrand Aggregates in Road Construction (UNBAR) Reykjavik, 62 p.

BS, 1975. Methods for sampling and testing of mineral aggregate and filters.BS 812 .

BS, 1989. Methods of determination of particle shape. BS 812 105.1, BSI, Flakiness index London., pp. 1-10.

BS, 1990. Testing aggregates Part 105. Methods for determination of particle shape. BS 812 105.2, Elongation index, London, pp 1-12.

BS, 1995. Testing aggregates. BS. 812 Part 2. Methods of determination

of density. pp. 1-22.

Dhakal, G.P., Kodma, J., and Goto, J., 2006. FreezingThawing effect and slake durability of some rocks from cold regions of Nepal and Japan. Nepal Geological society, Vol. 33, pp. 45-54.

DOR, 2001. Standard Specification for Road and Bridge Works, Report of Ministry of Physical Planning and Works, pp. 600-1200.

Khanna, S.K. and Justo CEG, 2004. Highway and Material Testing a Laboratory Mannual, Nemchand and Bros, Roorkee Press, pp.2-94.

Maharjan, D.K. and Tamrakar, N.K., 2003. Quality of Siltstones for Concrete Aggregates from NalluKhola Area, Kathmandu, Nepal Geological Society, vol. 30, pp. 167-176.

Maharjan, S. and Tamrakar, N.K., 2007. Study of Gravel of the Narayani and Rapti River for Construction Materials, Bulletin of Department of Geology, T.U., vol. 10., pp. 99-106. doi: 10.3126/bdg.v10i0.1425

Nepal Standard and Measurement Bureau, 1994. Specification for aggregates (NS-297-2050) U.D.C N620, 113p.

Roberts, F.L.; Kandhal, P.S.; Brown, E.R.; Lee, D.Y. and Kennedy, T.W. (1996). Hot Mix Asphalt Materials, Mixture Design, and Construction. National Asphalt Pavement Association Education Foundation. Lanham, MD:http://www.pavementinteractive.org/article/Grada tion-Test/\#sthash.HL6Kqyjh.dpuf

Smith, M.R. and Collis, L., 1993. Sand, Gravel and Crushed Rock Aggregates for Construction Purpose, Geo. Soc. London, Specia; Publication, Vol. 9, pp. 5-263

Stöcklin, J., 1981. Geology of Nepal and its regional Frame. Journal of the Geological Society of London, 137, pp. 1-34.

http://dx.doi.org/10.1144/gsjgs.137.1.0001

Stöcklin, J., Bhattarai, K.D., 1977. Geology of the Kathmandu area and central Mahabharat range, Nepal Himalaya. Report of Department of Mines and Geology/ U N D P ( u n p u b i s h e ), $86 \mathrm{p}$. http://dx.doi.org/10.1144/gsjgs.137.1.0001

Tamrakar, N. K., Yokota, S. and Shrestha S. D., 2002. Physical and geomechanical properties of the Siwalik Sandstones, Amlekhgunj-Suparitar Area, Cenetral Nepal Himalaya, Journal of Nepal Geological Society, Vol. 26, pp. 59-71.

http://dx.doi.org/10.1016/j.enggeo.2006.10.005 